Sains Malaysiana 48(8)(2019): 1697-1706

http://dx.doi.org/10.17576/jsm-2019-4808-15

\title{
An in vitro Three-Dimensional Co-Culture System for Ameloblastoma Modelling
}

(Sistem Ko-Kultur Tiga Dimensi secara in vitro untuk Pemodelan Ameloblastoma)

\section{Soo Leng LeE*, Zainal Ariff Abdul Rahman, Hidetsugu Tsujigiwa, Mei Hamada, Kiyofumi TaKabataKe, KeISUKE NAKANO, HitOSHI NAGATSUKA \& CHONG HUAT SiAR}

\begin{abstract}
Ameloblastoma, the most clinically significant odontogenic epithelial tumor, is a locally-invasive and destructive lesion in the jawbones. However, the nature of this infiltrativeness and destructive behavior remains ill-understood. To address this, we established an in vitro three-dimensional $(3 D)$ co-culture system to simulate an amelobastoma disease model aimed at investigating the interactions between tumor cells and osteoblasts. Osteoblastic cell lines (KUSA/A1 and MC3T3-E1) and one stromal cell line (ST2) were separately co-seeded with ameloblastoma-derived cell line (AM-1) in a collagen scaffold (representing the extracellular bone matrix) and incubated with mineralization medium. Immunohistochemistry, double immunofluorescence and mineralization assay were performed. Only AM-1/KUSA-A1 co-culture showed a significant increase in AM-1 cell count, suggesting that heterotypic cell-cell interaction promotes tumoral cell growth, while formation of visible AM-1 epithelial nest-like structures resembling ameloblastoma cells in their native state, suggest morphodifferentiation. A RANK-high, RANKL-low and osteoprotegerin-low immunoprofile in co-culture AM-1 cells implies deregulated osteoclastogenesis. Mineralization assays showed diminished calcification in AM-1/KUSA-A1 co-culture extracellular matrix suggesting an altered local bone metabolism. In contrast, KUSA/A1 monocultures showed abundant extracellular matrix calcification. Taken together, these results suggest that a $3 \mathrm{D}$ co-culture system as an amelobastoma disease model provides insights that bidirectional ameloblastoma-osteoblastic interactions might play a role in modulating tumor growth and osteoclastogenesis.
\end{abstract}

Keywords: Ameloblast; ameloblastoma modelling; co-culture system; pre-osteoblast

ABSTRAK

Ameloblastoma, tumor epitelium odontogenik yang paling umum secara klinikal, ialah lesi invasif setempat dan lesi memusnah yang didapati di tulang rahang. Walau bagaimanapun, sifat penyusupan dan perilaku yang merosakkan masih tidak difahami. Untuk menangani ini, kami menubuhkan satu sistem in vitro tiga dimensi (3D) untuk mensimulasikan model penyakit amelobastoma, bertujuan untuk mengkaji interaksi antara tumor dan sel osteoblastik. Sel-sel osteoblastik (KUSA/ A1 dan MC3T3-E1) dan satu sel stromal (ST2) bersandarkan dengan sel-sel tumor ameloblastoma, AM-1 secara berasingan dalam gel kolagen (mewakili matriks tulang ekstrasel) dan diinkubasi dengan medium pemineralan. Imunohistokimia, imunopendarfluor ganda dua dan asai mineral dijalankan. Hanya kultivar AM-1/KUSA-A1 menunjukkan kenaikan ketara dalam jumlah sel AM-1, menunjukkan bahawa interaksi sel heterotip menggalakkan pertumbuhan sel tumor, manakala pembentukan struktur seperti sarang epitelium AM-1 kelihatan sebagai sel ameloblastoma dalam keadaan asalnya, mencadangkan pembezaan morfotip. RANK-Tinggi, RANKL-rendah dan osteoprotegerin-rendah imunoprofil dalam ko-kultur dengan sel AM-1 mencadangkan osteoklastogenesis yang tidak terkawal. Pemineralan asai juga menunjukkan bahawa kalsifikasi dalam matriks ekstrasel AM-1/KUSA-A1 telah mencadangkan perubahan dalam metabolisme tulang setempat. Sebaliknya, monokultur KUSA/A1 menunjukkan kalsifikasi matriks ekstrasel yang signifikan. Secara eksplisit, keputusan ini menunjukkan bahawa sistem ko-kultur 3D sebagai model penyakit amelobastoma memberikan pandangan terperinci terhadap interaksi antara ameloblastoma dan osteoblas dan keupayaannya untuk memainkan peranan penting dalam pengubahan pertumbuhan tumor dan osteoklastogenesis.

Kata kunci: Ameloblas; pemodelan ameloblastoma; pra-osteoblas; sistem ko-kultur

\section{INTRODUCTION}

Ameloblastoma, the most common and clinically significant odontogenic epithelial neoplasm, accounts for approximately $11 \%$ to $18 \%$ of all odontogenic tumors (Ringer \& Kolokythas 2017; Vered et al. 2017; Wright \& Vered 2017). Although clinically benign, it is characterized by a locally-invasive and osseo-destructive behavior and a high rate of recurrence (Vered et al. 2017). According to the 2017 World Health Organization Classification of Head and Neck Tumors, four categories were classified: conventional, extraosseous/peripheral, unicystic, and metastasizing ameloblastoma (Vered et al. 2017; Wright $\&$ Vered 2017). In cancers, recent research efforts have increasingly focused on in vitro $3 \mathrm{D}$ models including 
metastatic bone models to better understand tumor-stromal interactions (Fong et al. 2016; Kim \& Othmer 2013; Liu et al. 2016; Luis-Ravelo et al. 2011; Wendler et al. 2016). Less appreciated are parenchyma-osteoblast interactions and their potential role in regulating tumoral growth and local invasiveness in ameloblastoma. In the present study, we constructed an in vitro $3 \mathrm{D}$ co-culture system to simulate an ameloblastoma disease model aimed at elucidating the effects of heterotypic cell-cell interactions on tumoral growth and bone turnover. The rationale was to gain some insights into the cellular dynamics of this neoplasm.

\section{MATERIALS AND METHODS}

\section{MONOLAYER 2D CELL CULTURE}

The ameloblastoma cell line, AM-1 was established by Dr. Hidemitsu Harada from Iwate Medical University, Japan. A mouse pre-osteoblastic cell line, KUSA/A1 was courtesy of Dr. Akihiro Umezawa from Keio University, Tokyo, Japan. The stromal cell line ST2, derived from mouse bone marrow and the immortalized mouse osteoblastic cell line, MC3T3-E1 were obtained from RIKEN BRC (Tsukuba, Japan). AM-1 cells were cultured in keratinocyte-serum free medium (K-SFM) supplemented with $1 \mathrm{ng} / \mathrm{mL}$ recombinant epithelial growth factor (EGF) and $50 \mu \mathrm{g} / \mathrm{mL}$ bovine pituitary extract (BPE) (all from GIBCO, El Paso, TX, USA). KUSA/A1, ST2 and MC3T3-E1 cells were cultured in Minimal Essential Alpha Medium ( $\alpha$-MEM, GIBCO, USA) supplemented with $10 \%$ fetal bovine serum (GIBCO, Burlington, ON, Canada) and $1 \%$ antibioticantimycotic (GIBCO, USA). Cells were seeded on $100 \mathrm{~mm}$ culture dishes (Sigma-Aldrich, St. Louis, MO, USA) and incubated at $37^{\circ} \mathrm{C}$ in humid air with $5 \% \mathrm{CO}_{2}$. The cell culture medium was changed every 3 days until the cells were nearly confluent and passage using $0.05 \%$ trypsinethylenediaminetetraacetic acid (EDTA) (GIBCO, Canada).

\section{GROWTH OF 3D in vitro MODEL}

Atelocollagen, Eagle's MEM (Koken, Tokyo, Japan) gels formed the basis of $3 \mathrm{D}$ cellularized models. In vitro $3 \mathrm{D}$ culture of single cell types: KUSA/A1, ST2, MC3T3-E1 and AM-1 were prepared by harvesting cells from confluent monolayer cultures using $0.05 \%$ trypsin-EDTA (GIBCO, Canada) and Accutase (Innovative Cell Technologies, San Diego, CA, USA). These were counted, adjusted to the desired cell density, and centrifuged at 1,000 $\mathrm{g}$ for $1 \mathrm{~min}$ in a $50 \mathrm{~mL}$ centrifuge tube at room temperature. The tube was placed on ice, and the cell pellet obtained was re-suspended in a solution of polymerizing collagen which was prepared by quickly mixing 1 volume of atelocollagen with 1 volume of mineralization medium ( $\alpha$-MEM containing $50 \mu \mathrm{g} / \mathrm{mL} \mathrm{L-ascorbic} \mathrm{acid} \mathrm{and} 5 \mathrm{mM}$ $\beta$-glycerophosphate) (all from Sigma-Aldrich, Dorset, England, UK) at a density of $8.0 \times 10^{5}$ cells $/ \mathrm{cm}^{3}$. Aliquots $(0.5 \mathrm{~mL})$ of the cold collagen mixture were dispensed into 24-well culture plates and allowed to gel for about $90 \mathrm{~min}$ at $37^{\circ} \mathrm{C}$ before the addition of mineralization medium. In the meantime, three variations of in vitro $3 \mathrm{D}$ co-culture were prepared by adding a total of $8.0 \times 10^{5}$ cells $/ \mathrm{cm}^{3}$ in each well of a 24-well culture plate at 1:1 ratio of AM-1 to osteoblastic (KUSA/A1 and MC3T3-E1) and fibroblastic (ST2) cells in a total volume of $0.5 \mathrm{~mL}$ of polymerizing collagen mixture, and allowed to gel for $90 \mathrm{~min}$ at $37^{\circ} \mathrm{C}$ prior to the addition of mineralization medium. The $3 \mathrm{D}$ monocultures (AM- $1, n=3$; KUSA-A $1, n=3$; ST2, $n=3$; MTCT3-E1, $n=3$ ) and the co-culture constructs (AM-1/ KUSA-A1, $n=12$; AM-1/ST2, $n=12$; AM-1/MTCT3-E1, $n=12$ ) were incubated at $37^{\circ} \mathrm{C}$ in humid air with $5 \% \mathrm{CO}_{2}$ at the same time and the mineralization medium was changed every 3 days. These cell culture constructs were harvested and analyzed at 3, 7, and 14 days.

\section{CELL MORPHOLOGY ANALYSIS}

All specimens from monocultures of single cell types (AM- $1, n=3$; KUSA-A1, $n=3$; ST2, $n=3$; MTCT3-E1,$n=3$ ) and co-culture constructs (AM-1/KUSA-A $1, n=12 ; \mathrm{AM}-1 / \mathrm{ST} 2$, $n=12$; AM-1/MTCT3-E1, $n=12$ ) were fixed in $10 \%$ formalin, embedded in paraffin and cut into $10 \mu \mathrm{m}$ thick sections for hematoxylin (Merck KGaA, Darmstadt, Germany) and eosin (Waldeck KG, Münster, Germany) (H\&E) staining. Cellular morphology analysis was performed using the Olympus BX43 upright microscope (Olympus, Tokyo, Japan) equipped with a DP27 color camera (Olympus, Tokyo, Japan) and CellSens software (CellSens Imaging Software, Olympus, Tokyo, Japan).

\section{IMMUNOHISTOCHEMISTRY}

For all specimens from monocultures (AM- $1, n=3$; KUSA-A1, $n=3$; ST2, $n=3$; MTCT3-E1, $n=3$ ) and two specimens per time point from co-culture constructs (AM-1/KUSA-A1, $n=6$; AM-1/ST2, $n=6$; АM-1/MTCT3-E1, $n=6), 10 \mu \mathrm{m}$ thick paraffin sections were cut and mounted on Matsunami adhesive slide (MAS)-coated slides (Matsunami, Tokyo, Japan). These were deparaffinized in series of xylene (Muto Pure Chemicals, Tokyo, Japan) for $15 \mathrm{~min}$ and rehydrated in graded ethanol solutions (Japan Alcohol Trading, Tokyo, Japan). Antigen retrieval was achieved by $0.1 \%$ trypsin treatment $\left(37^{\circ} \mathrm{C}, 15 \mathrm{~min}\right)$ (GIBCO, Canada) for mouse monoclonal anti-cytokeratin (IS053) (Dako, Glostrup, Denmark; diluted 1:50) or heat treatment using $10 \mathrm{mM}$ citrate buffer solution made from $1.72 \mathrm{~g}$ of citric acid (Sigma-Aldrich, Tokyo, Japan) and $13.0 \mathrm{~g}$ of trisodium citrate dihydrate (Kanto Chemical, Tokyo, Japan) (pH 6, 5 min, 300W) for rabbit monoclonal anti-vimentin (ab92547) (Abcam, Cambridge, MA, USA; diluted 1:200), mouse monoclonal RANK (ab13918) (Abcam, diluted 1:200), mouse monoclonal RANKL (ab45039) (Abcam, 1:400), and rabbit polyclonal osteoprotegerin (OPG) (ab9986) (Abcam, 1:100). After treatment with normal serum (Dako for Envision technique; and Vector Laboratories, Burlingame, CA, USA for avidin-biotin complexes technique), the sections were incubated with primary antibodies at $4^{\circ} \mathrm{C}$ overnight. The tagging of primary antibody was achieved 
using Envision peroxidase mouse detection reagent (Dako) or by the subsequent application of anti-rabbit IgG biotinylated antibody and avidin-biotin complexes (Rabbit ABC kit, Vector Laboratories, USA). The visualization of immunoreactivity was performed using diaminobenzidine (DAB) $/ \mathrm{H}_{2} \mathrm{O}_{2}$ solution (Nacalai Tesque, Kyoto, Japan) and counterstained with Mayer's hematoxylin (Merck $\mathrm{KGaA}$ ). Known positive sections of oral olfactory bulb for cytokeratin and vimentin, central giant cell granuloma for RANK, RANKL and OPG were used as positive controls. For negative control, sections were treated as mentioned, but without the application of primary antibody. All control sections were negative.

\section{IMMUNOHISTOCHEMICAL ANALYSIS}

The digitized images were acquired using the Olympus BX43 upright microscope equipped with a DP27 color camera and CellSens software (all from Olympus). The protein staining and immunoreactivity for all markers in the mono- and co-culture constructs were visualized at 200x magnification. Immunostaining was scored as negative $(-)$ when none of the cells were positively stained in the cytoplasm, membrane or nucleus; mild $(+),<25 \%$ cells positive; moderate $(++), 25-50 \%$ cells positive; and strong $(+++),>50 \%$ cells positive.

\section{DUAL LABEL IMMUNOFLUORESCENCE}

Dual immunofluorescence staining was performed on one representative specimen selected from day 3 co-culture constructs (AM-1/KUSA-A1, $n=1$ ). Briefly, formalin-fixed paraffin-embedded gels were incubated with bovine serum albumin (DS Pharma Biomedical, Osaka, Japan) to block non-specific binding. Following that, slides were incubated with primary mouse monoclonal anti-pan cytokeratin (ab27988) (Abcam; diluted 1:50) and rabbit monoclonal anti-vimentin (ab92547) antibody at $4^{\circ} \mathrm{C}$ overnight. After $0.05 \mathrm{M}$ Tris-buffered saline (TBS) washes, slides were incubated with goat anti-mouse IgG H\&L (Alexa Fluor 568) (ab175473) (Abcam) and goat anti-rabbit IgG H\&L (Alexa Fluor 488) (ab150077) (Abcam) for $1 \mathrm{~h}$ at room temperature. The sections were then counterstaining with 4', 6-diamidino-2-phenylindole (DAPI) (Nacalai Tesque), nucleic acid dye, mounted and viewed under Zeiss LSM 780 laser scanning confocal microscope (Carl Zeiss, Oberkochen, Germany).

\section{MINERALIZATION ASSAY}

For analysis of mineralized nodule formation, all samples from the osteoblastic cell monocultures (KUSA-A1, $n=3$; MTCT3, $n=3$ ) and two specimens per time point of co-culture constructs (AM-1/KUSA-A $1, n=6$; AM-1/ST2, $n=6$; AM- 1 / MTCT3-E1, $n=6$ ) were incubated in the inducing condition (addition of ascorbic acid and $\beta$-glycerophosphate) and Alizarin red S (Sigma-Aldrich, Tokyo, Japan) staining was performed. Briefly, the harvested cell culture constructs were fixed in $10 \%$ formalin, embedded in paraffin, cut into $10 \mu \mathrm{m}$ thick sections and subsequently stained with Alizarin Red S solution for $5 \mathrm{~min}$. The remaining staining dye was washed away with distilled water and sections visualized by Olympus BX43 upright microscope equipped with a DP27 color camera and CellSens software (all from Olympus).

\section{CELL COUNTING}

At each time point, the number of cytokeratin- and vimentin-positively stained cells was counted at $200 \times$ magnification from the selection regions in the mono- and co-culture constructs. In each section, quantification was performed using ImageJ, a Java-based image processing program developed at the National Institutes of Health for Windows. Relative cell number in both configurations was calculated from 5 randomly selected defined regions of interest in each case. Results were expressed as means + standard deviation (SD).

\section{STATISTICAL ANALYSIS}

All experiments were conducted in duplicates with the same passages of the cell lines. Statistical analysis was performed using IBM SPSS software version 18.1 (IBM, Armonk, NY, USA) for Windows. Data on cell count were presented as means $+\mathrm{SD}$. Comparisons between mean variables of two groups were performed using the Student t test. Level of significance was set as $p<0.05$.

\section{RESULTS}

\section{MORPHOLOGICAL CHARACTERISTICS OF 3D MONOCULTURE CELLS}

At culture day 3, KUSA/A1 and MC3T3-E1 cells formed irregular clusters composed of round and elongated shapes (not shown). From culture day 7 to 14, KUSA/A1 cell clusters increased in size (Figure 1(A)-1(C)) but MC3T3-E1 cell aggregates remained relatively dispersive throughout the matrix (not shown). ST2 cells were sparsely scattered throughout the collagen scaffold and no cell aggregates were observed throughout the culture period (not shown). AM-1 cell lines, on the other hand, were mainly scattered in a dissociated manner as round shapes with occasional cluster formation (Figure 1(D)-1(F)).

\section{MORPHOLOGICAL CHARACTERISTICS OF 3D CO-CULTURE CELLS}

From culture day 3 onwards, co-culture of AM- 1 with KUSA/ A1 cells showed a heterogeneous cell population with two distinct morphologies (Figure 2(A)-2(C)). AM-1 cells presented as small round to avoid cells with an epithelial morphology and these cells were organized into nest-like aggregates while the interspersed KUSA/A1 cells were identified as elongated spindle-shaped cells with long anastomosing cytoplasmic processes (Figure 2(A)-2(C)) These morphological alterations were not seen in both AM-1 
Day 3
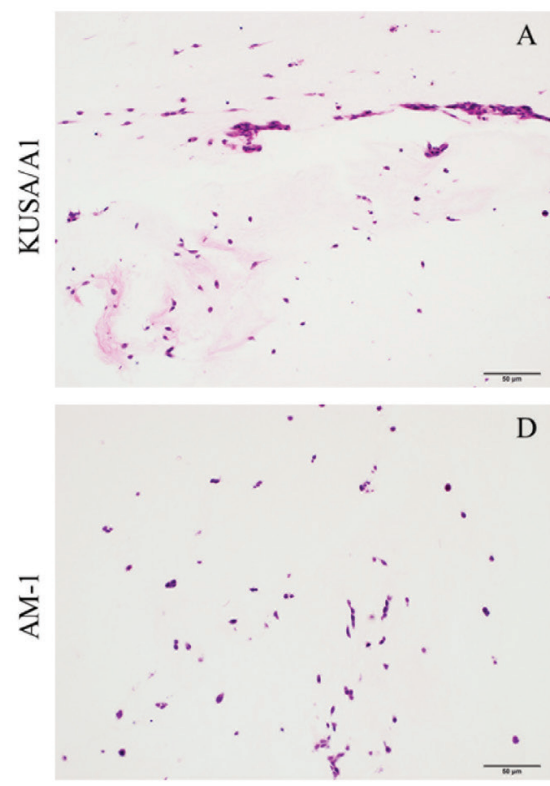

Day 7
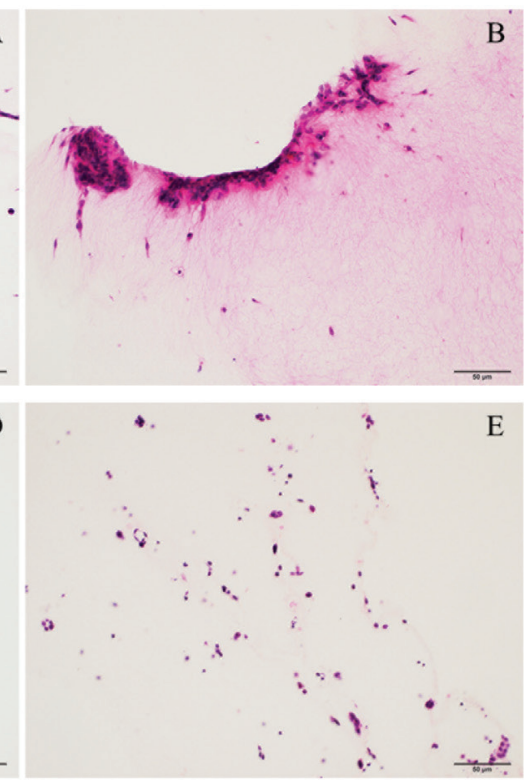

Day 14
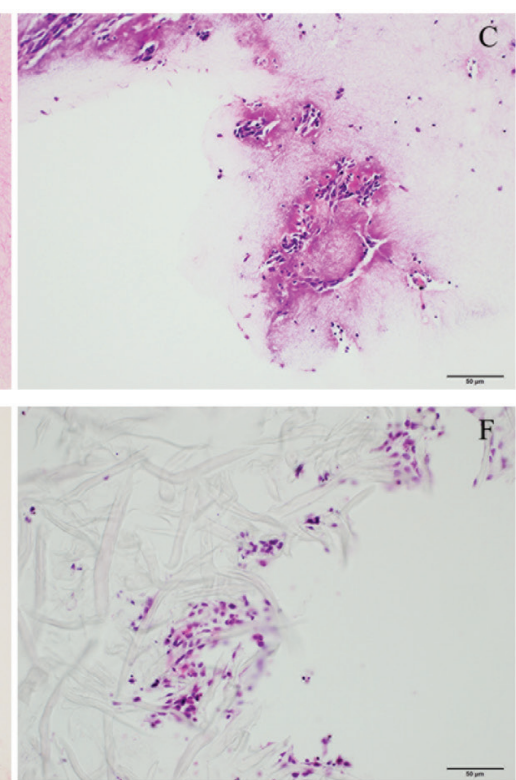

FIGURE 1. Representative microscopic images of KUSA/A1 and AM-1 monocultures in 3D at different time points - day 3 (A, D), day 7 (B, E) and day 14 (C, F) (H\&E stain; Original magnification: $\times 200)$
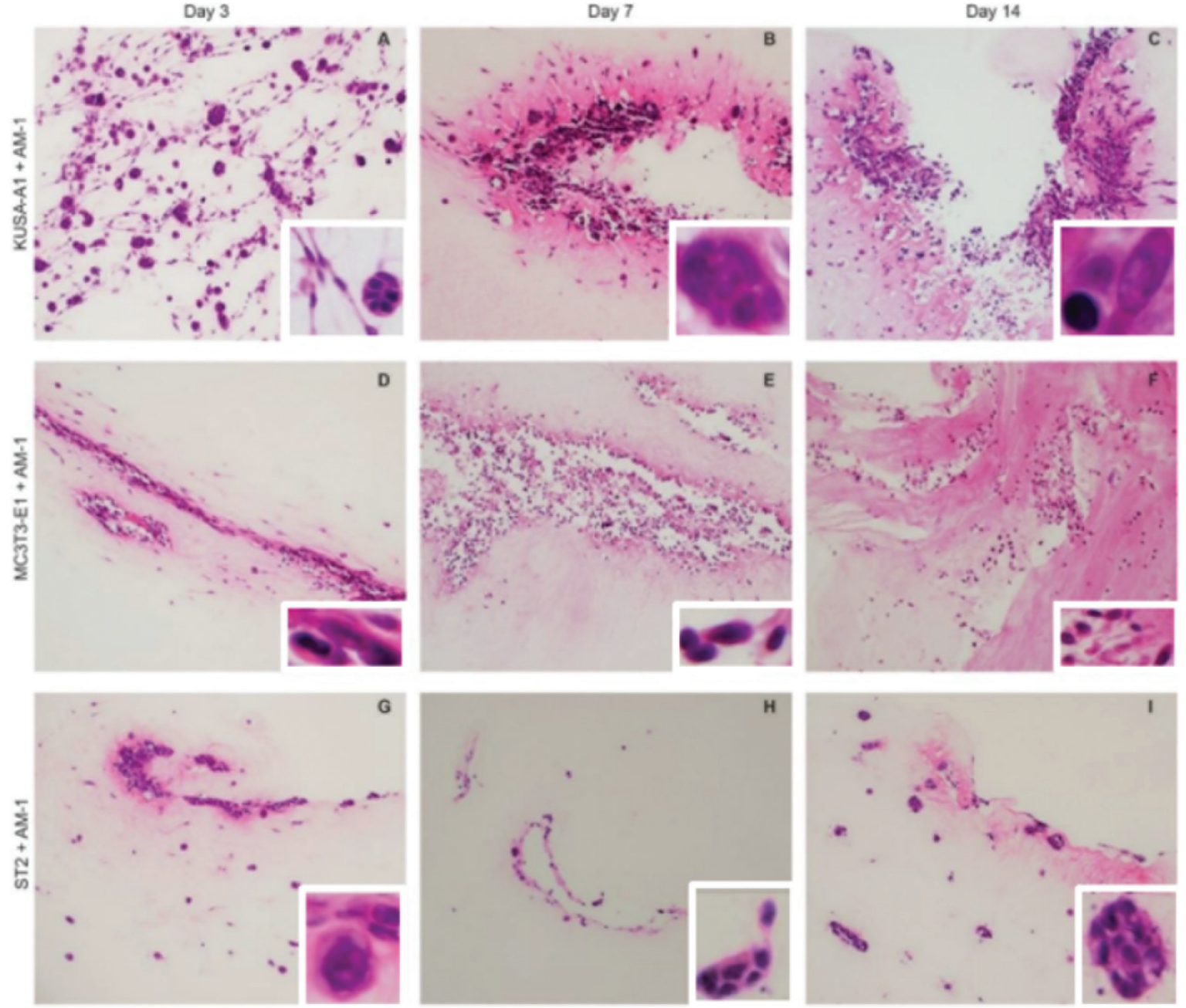

FIGURE 2. Representative microscopic images showing the growth of co-cultures in 3D of different cell density at different time points - day $3(\mathrm{~A}, \mathrm{D}, \mathrm{G})$, day 7 (B, E, H) and day 14 (C, F, I) (H\&E stain; Original magnification: A-I, ×200; Insets A-I, ×400) 
co-cultures with MC3T3-E1 (Figure 2(D)-2(F)) and ST2 cells (Figure 2(G)-2(I)) throughout the experimental period.

\section{IMMUNOHISTOCHEMICAL AND IMMUNOFLUORESCENCE} CHARACTERISTICS OF MONO- AND CO-CULTURE CELLS

Cytokeratin was strongly expressed by AM-1 cells in monoculture (not shown) and nest-like aggregates in 3D co-culture (Figure 3(A)-3(C)). Vimentin immunoreactivity was detected in KUSA/A1 cells in monoculture (not shown) and flat elongated spindle-shaped cells in 3D co-culture and weak-to-absent in AM-1 cells (Figure 3(D)-3(F)). Immunofluorescence dual labelling confirmed round cell aggregates as cytokeratin-positive (Figure 4(A), 4(B)) and elongated spindle-shaped cells as vimentin-positive (Figure 4(A), 4(C)). Both round cell nest-like structures and elongated spindle-shaped cells in co-culture strongly expressed RANK, mildly for RANKL and OPG (Figure $5(\mathrm{~A})-5(\mathrm{C}))$.
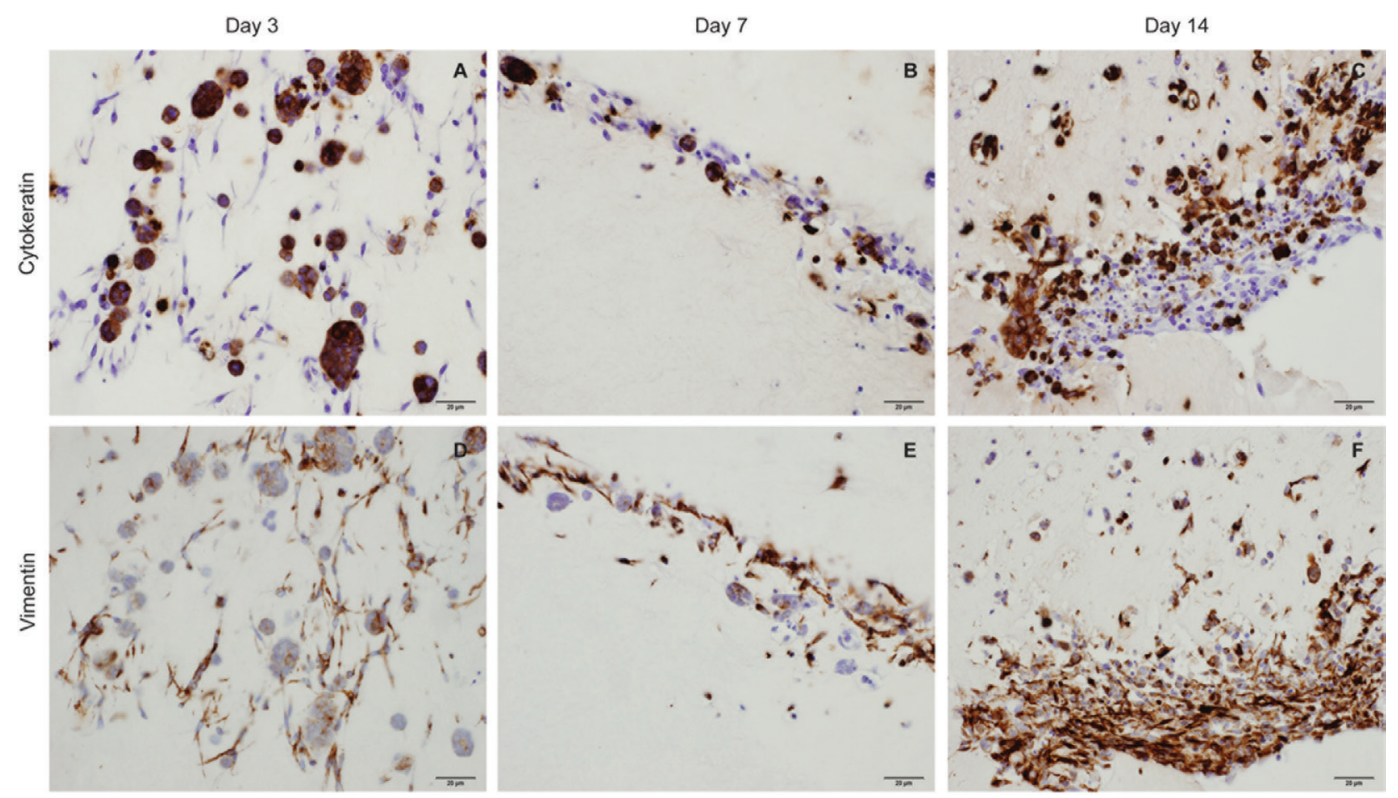

FIGURE 3. Representative immunohistochemical images showing AM-1/KUSA-A1 co-culture construct of cell density at $2.5 \times 10^{5} /$ cell type expressing cytokeratin (A-C) and vimentin (D-F) staining at different time points - day 3 (A, D), day 7 (B, E) and day $14(\mathrm{C}, \mathrm{F})$. The experiments were performed in duplicates. Bar=20 micron

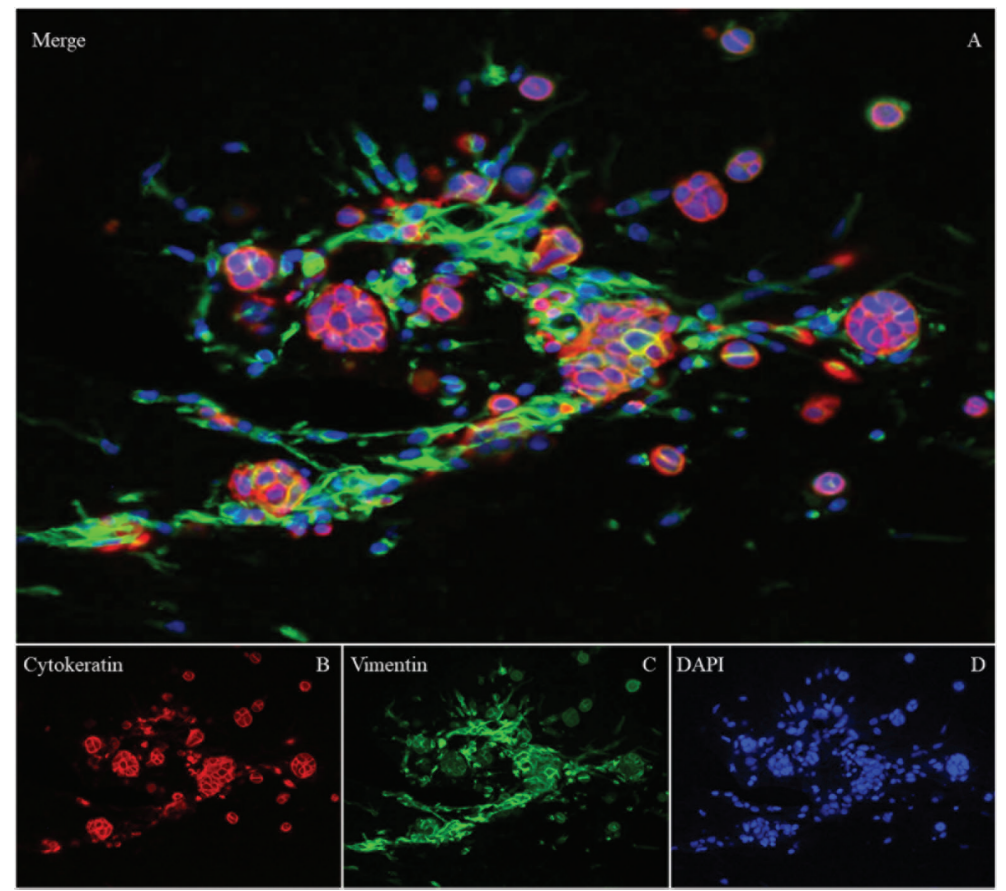

FIGURE 4. Representative sections of KUSA/A1 and AM-1 co-culture constructs showing immunofluorescent staining for cytokeratin (red), vimentin (green) and DAPI (blue) (A-D). Cytokeratin reaction was strong in the membrane and cytoplasm of round nest-like structures (A, B). Vimentin expression was strong and predominantly membranous in elongated spindle-shaped cells $(A, C)$. Nuclei are counterstained with DAPI (D) (Original magnification: A-D, ×200) 


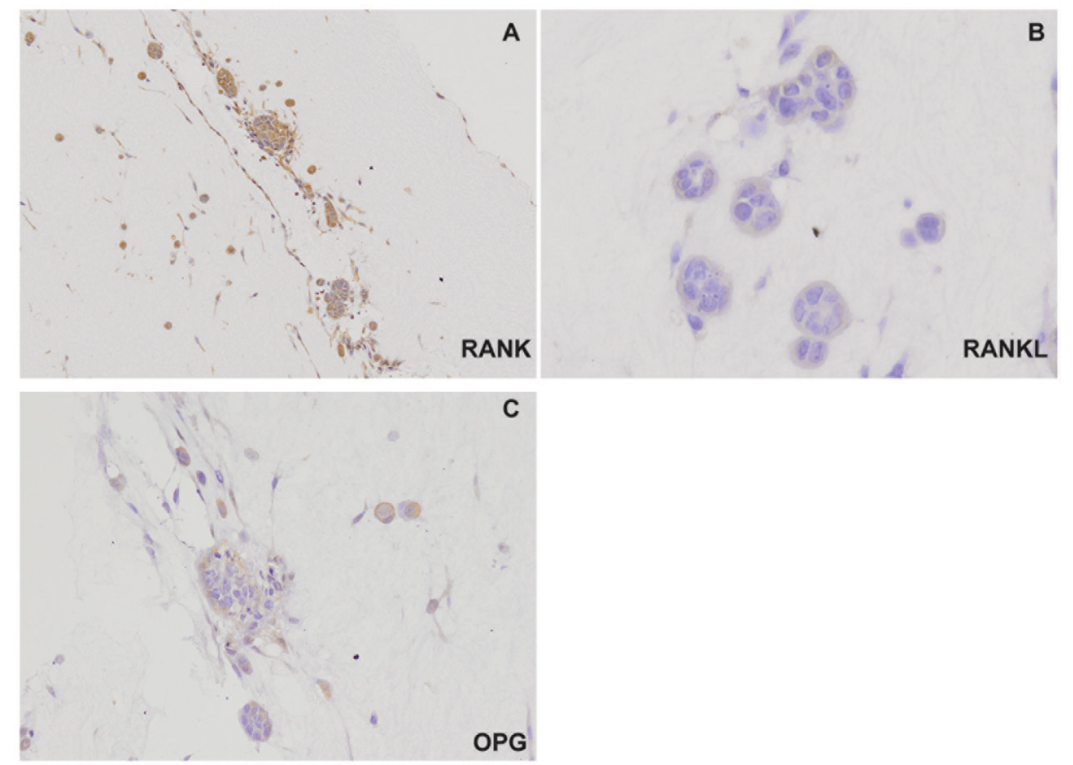

FIGURE 5. Representative sections of KUSA/A1 and AM-1 co-culture constructs showing immunohistochemical staining for RANK, RANKL and osteoprotegerin (OPG) (A-C). RANK reaction was strong in the membrane and cytoplasm of round nestlike structures and elongated spindle-shaped cells (A), RANKL expression was weak to absent in the cytoplasm of both cell types (B), and OPG was weakly expressed in both cell types (C) (Original magnification: A-C, ×200)

\section{MINERALIZATION CHARACTERISTICS OF MONO- AND CO-CULTURE CELLS}

No visible extracellular matrix mineralization was observed in mono- and co-cultures during the first week of experiment (Figure 6(A)-6(F)). After culture day 14, KUSA/A 1 cells in monoculture shown evidence of intense extracellular matrix mineralization as confirmed by intense Alizarin red S staining (Figure 6(H)), whilst KUSA/A1 cells in the AM-1 co-culture shown reduced Alizarin Red S staining (Figure 6(G)). No visible Alizarin red S staining in AM-1 cell monoculture was observed (Figure 6(I)).

\section{CELL COUNT OF MONO- AND CO-CULTURE CELLS}

Immunoreactivity scores for cytokeratin, vimentin, RANK, RANKL and OPG for KUSA/A1 and AM-1 cells in mono- and co-culture constructs at different time points are shown in Tables 1 and 2. Both KUSA/A1 and AM-1 in co-cultures showed a drop in cell count at day 7 but regained back at day 14. At the end of culture period (day 14) both KUSA/ A1 and AM-1 in co-cultures showed a significant increase in cell count compared to their monoculture counterparts $(p<0.05)$.

\section{DISCUSSION}

Unlike human cancers, fewer in vitro studies have investigated the role of tumor-stromal interactions on tumor properties and its dynamics in ameloblastoma (Chantravekin \& Koontongkaew 2014; Eriksson et al. 2016; Fuchigami et al. 2014; Sathi et al. 2009, 2008; Takebe et al. 2017). Thus far, it is known that parenchymastromal secreted SFRP-2 is implicated in bone resorption (Sathi et al. 2009, 2008). Evidently, interaction between ameloblastoma cells and stromal fibroblasts via IL-6 and IL- 8 created a microenvironment conducive for ameloblastoma extension (Fuchigami et al. 2014), the parenchyma-stromal derived $\mathrm{CCN} 2$ induces fibrosis and promotes osteoclastogenesis in ameloblastoma (Takebe et al. 2017), and that ameloblastoma cells co-cultured with osteosarcoma cells led to RANKL upregulation (Eriksson et al. 2016). Most of these works were based on twodimensional (2D) cell cultures which do not reflect the in vivo tumor state (Liu et al. 2016). A most recent study utilized a 3D organotypic co-culture model (Eriksson et al. 2016). Cells in 2D formats undergo proliferation and then de-differentiation, consequently losing their essential functions. In contrast, cells grown in 3D culture are more physiologically relevant in terms of proliferation, differentiation, morphology and cellular functionality (Antoni et al. 2015).

In this study, we established an in vitro $3 \mathrm{D}$ co-culture system where KUSA/A1 (pre-osteoblastic cell lines), MC3T3-E1 (osteoblastic cell lines) and ST2 (stromal cell lines) were separately co-seeded with AM-1 (ameloblastoma cell lines) (Harada et al. 1998; Umezawa et al. 1992). This was fabricated to simulate the ameloblastoma disease model aimed at gaining some insights into the interactions between ameloblastoma and osteoblasts and relate them to the growth and osteoclastogenesis in this neoplasm. To achieve this objective, these co-culture systems with the cultivated cells suspended in the 3D collagen gel space in situ were harvested at specific time-points, and probed using immunohistochemistry, dual immunofluorescence and mineralization assays.

A key finding in the present study was significant increase in the number of AM-1 cells in $3 \mathrm{D}$ co-cultures 
TABLE 1. Immunoreactivity scores for cytokeratin, vimentin, RANK, RANKL and osteoprotegerin (OPG)

\begin{tabular}{lcccc}
\hline \multirow{2}{*}{ Factors } & \multicolumn{2}{c}{ Monoculture cell lines } & \multicolumn{2}{c}{ Co-culture cell lines } \\
\cline { 2 - 5 } & KUSA/A1 & AM-1 & KUSA/A1 & AM-1 \\
\hline Cytokeratin & - & +++ & - & ++++ \\
Vimentin & +++ & - & +++ & +++ \\
RANK & + & + & + & +++ \\
RANKL & \pm & \pm & + & + \\
OPG & - & - & +
\end{tabular}

,- no positive cell $;+,<25 \%$ of cells positive $;++, 25 \%$ to $50 \%$ of cells positive;,$+++>50 \%$ of cells positive

TABLE 2. Statistical analysis of mean \pm SD cell count at different time points for KUSA/A1 and AM-1 cell lines in 3D mono- and co-cultures

\begin{tabular}{|c|c|c|c|c|c|c|c|c|c|c|}
\hline \multirow{2}{*}{$\begin{array}{c}\text { Period } \\
\text { (day) }\end{array}$} & \multicolumn{4}{|c|}{ KUSA/A1, mean \pm SD (range) } & \multirow[t]{2}{*}{$p$-value } & \multicolumn{4}{|c|}{ AM- 1, mean \pm SD (range) } & \multirow[t]{2}{*}{$p$-value } \\
\hline & $\mathrm{n}$ & Monoculture & $\mathrm{n}$ & Co-culture & & $\mathrm{n}$ & Monoculture & $\mathrm{n}$ & Co-culture & \\
\hline 3 & 1 & $137.2 \pm 36.27$ & 2 & $163.8 \pm 56.62$ & 0.0536 & 1 & $117.6 \pm 44.91$ & 2 & $206.2 \pm 76.92$ & 0.0629 \\
\hline 7 & 1 & $186.2 \pm 98.15$ & 2 & $135.8 \pm 35.85$ & 0.0148 & 1 & $172.6 \pm 49.13$ & 2 & $135.8 \pm 77.55$ & 0.0046 \\
\hline 14 & 1 & $243.8 \pm 100.59$ & 2 & $256 \pm 237.41$ & 0.0319 & 1 & $63.2 \pm 52.3$ & 2 & $229 \pm 118.62$ & 0.0161 \\
\hline
\end{tabular}

$\mathrm{n}$, number of samples; Bold values indicate statistical significance. $p<0.05$

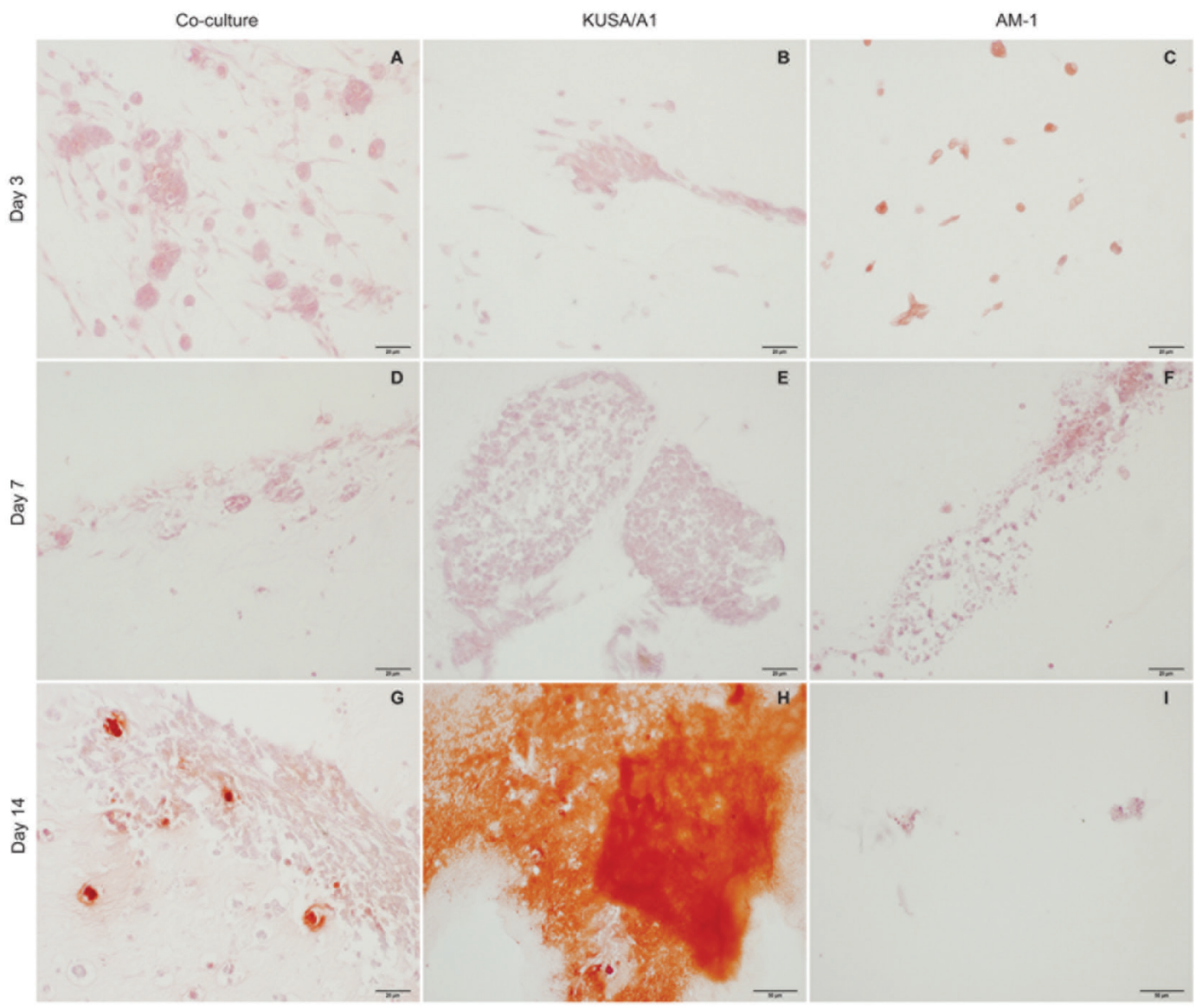

FIGURE 6. Representative sections of KUSA/A1 and AM-1 in mono- and co-culture constructs showing no visible extracellular matrix mineralization during first week of experiment (A-F). KUSA/A1 cell cultured in 3D at day 14 shows intense Alizarin red $\mathrm{S}$ staining evidence of diffuse mineralization $(\mathrm{H})$. However, co-culture construct shows reduced mineralization $(\mathrm{G})$. No visible Alizarin red S staining in AM-1 cell monoculture was observed throughout experiment (Original magnification: A-I, $\times 100$ ) 
compared to their monocultures. In contrast, cell count between co-culture and monoculture for KUSA/A1, MC3T3-E1 and ST2 was less distinctive at the end of the experiment. These observations imply that ameloblastomaosteoblastic interactions may have a promotive effect on tumor cell growth and growth inhibitory effect on osteoblasts. The specific mechanism underlying this heterotypic interaction that stimulates tumor cell proliferation is unclear. It is known that AM-1 cells show downregulation of osteogenic genes including functional inactivation for WDR5, a factor which is essential for osteoblast differentiation (Sathi et al. 2012). In osteoblastic metastases, cancer cell produces osteoblast-stimulating factors to induce osteoblastogenesis and the activated osteoblasts in turn secrete factors to promote cancer colonization and growth (Ottewell 2016). Whether the latter signaling pathway occurs in ameloblastoma requires further investigation.

In the original work by Harada et al. (1998), primary culture AM-1 cells were described as predominantly closely-packed small and polygonal cells with an epithelial morphology. In the current study, AM-1 cells co-cultured with KUSA/A1 formed visible nest-like epithelial structures resembling ameloblastoma cells in their native state whilst KUSA/A1 remained as flat, elongated spindle-shaped cells. We interpreted this to mean that tumor-osteoblastic interactions induce morphodifferentiation of AM-1 cells but preservation of KUSA/A1 mesenchymal phenotype. The other notable observation was in the co-culture state, both cell types were in close proximity with each other. KUSA/ A1 cells with their long cytoplasmic processes interspersed and encircled AM-1 nest-like aggregates suggesting heterotopic cell-cell interaction. Despite this closeness, AM-1 and KUSA/A1 maintained fidelity of their lineages by expressing cytokeratin and vimentin, respectively. Lack of vimentin positivity in AM-1 cells further indicates absence of epithelial-to mesenchymal transition and phenotypic switching (Siar \& Ng 2014). It is known that intercellular communication between cancer and surrounding stromal cells creates a local microenvironment that promotes tumor survival and growth (Wendler et al. 2016). However, this feature of topographic closeness was not observed in AM-1 cells co-cultured with either MC3T3-E1 or ST2 cell lines. Emerging evidence suggests that differences in cell properties and genetic instability may be major reasons influencing interaction between these cells (Fong et al. 2016; Kim \& Othmer 2013; Liu et al. 2016).

In this study, a two-prong approach was used to assess local bone metabolism in the $3 \mathrm{D}$ co-culture system. Firstly, we examined KUSA/A1 and AM-1 in the co-culture construct for expression of bone remodeling molecules RANK, RANKL and OPG. A RANK-high, RANKL-low and OPG-low immunoprofile displayed by both cell types suggested a deregulated osteoclastogenesis. Osteoclasts are the cells responsible for bone resorption and the process of osteoclastogenesis is regulated by the complex RANK-RANKL-OPG pathway (Khosla 2001; Proff \& Romer
2009). Binding of RANKL to RANK triggers differentiation and activation of pro-osteoclasts (osteoclastic precursor cells) to mature (active) osteoclasts (Proff \& Romer 2009). This RANKL-RANK interaction is inhibited by OPG, a soluble decoy receptor for RANKL, resulting in osteoclast inactivation. Our results differed from previous in vitro studies where a 700-fold increase in RANKL was detected in co-culture of AM-1 and human osteosarcoma cell lines (Eriksson et al. 2016), RANKL and OPG were wellexpressed in AM-1 monoculture (Sandra et al. 2006) and in primary ameloblastoma co-cultured with neonatal rabbit bone marrow cells (Qian \& Huang 2010). The reasons for this variability in in vitro findings are unclear. One possible explanation may be ascribed to differences in cell lines, and types of cell culture system used (Eriksson et al. 2016). Other factors that might contribute to these disparities in findings include differences in the antibody sources used, methods related to tissue processing and histomorphometry. In clinicopathological studies, reports on RANK-RANKL-OPG expression levels based on surgical materials of ameloblastoma show variations in bone remodeling activities between primary and recurrent tumors (Andrade et al. 2008; da Silva et al. 2008; de Matos et al. 2013; Kumamoto \& Ooya 2004; Sandra et al. 2005; Siar et al. 2015; Tay et al. 2004; Tekkesin et al. 2011). A plausible explanation put forth is that RANKL up- or downregulation in ameloblastoma might be reflective of the dynamic on-going process associated with tumor-induced bone remodeling (Siar et al. 2015). In mineralization assays, KUSA/A1 monoculture demonstrated abundant Alizarin red $\mathrm{S}$ positive mineralized areas whereas this was diminished in the co-culture. These observations lend further support to our immunohistochemical findings which suggests that tumor-osteoblast interaction induces an altered local bone metabolism.

There are two main inherent limitations in this study. Firstly, the interspecies differences of these cell lines may compromise or confound attempts at relating the cellular interaction between ameloblastoma tumor cells and osteoblastic cells. The other issue is cell senescence which delimits the culture study period to 14 days. In view of these setbacks, an improved version of the in vitro 3D tumor-osteoblast co-culture model with eliminated interspecies differences and longer cell culture period is recommended to address the biologically appropriate cellcell interactions in this neoplasm.

\section{CONCLUSION}

In conclusion, we successfully established an in vitro 3D co-culture system to represent an amelobastoma disease model aimed at investigating tumor-osteoblast interactions. Our rationale was to gain some insights into the biological behavior of this enigmatic neoplasm. Present in vitro findings suggest that, ameloblastoma-osteoblast interactions might play an important role in modulating tumor growth and local bone metabolism. 


\section{ACKNOWLEDGEMENTS}

Our sincere thanks to Dr. Hidemitsu Harada from Iwate Medical University, Japan and Dr. Akihiro Umezawa from Keio University, Tokyo, Japan, for the gifts of AM-1 and KUSA/A1 cell lines, respectively, in this project. This study was jointly supported by the Ministry of Higher Education Malaysia Fundamental Research Grant Scheme (FP0322015A), University of Malaya Postgraduate Research Grant Scheme PG336-2016A, JSPS KAKENHI Grant No. 16K11441, 16K20577 and 26462783.

\section{REFERENCES}

Andrade, F.R., Sousa, D.P., Mendonca, E.F., Silva, T.A., Lara, V.S. \& Batista, A.C. 2008. Expression of bone resorption regulators (RANK, RANKL, and OPG) in odontogenic tumors. Oral Surg. Oral Med. Oral Pathol. Oral Radiol. Endod. 106(4): 548-55.

Antoni, D., Burckel, H., Josset, E. \& Noel, G. 2015. Threedimensional cell culture: A breakthrough in vivo. Int.J. Mol. Sci. 16(3): 5517-5527.

Chantravekin, Y. \& Koontongkaew, S. 2014. Effects of ameloblastoma-associated fibroblasts on the proliferation and invasion of tumor cells. J. Cancer Res. Ther. 10(4): 1082-1087.

da Silva, T.A., Batista,A.C., Mendonca, E.F., Leles, C.R., Fukada, S. \& Cunha, F.Q. 2008. Comparative expression of RANK, RANKL, and OPG in keratocystic odontogenic tumors, ameloblastomas, and dentigerous cysts. Oral Surg. Oral Med. Oral Pathol. Oral Radiol. Endod. 105(3): 333-341.

de Matos, F.R., de Moraes, M., das Neves Silva, E.B., Galvao, H.C. \& de Almeida Freitas, R. 2013. Immunohistochemical detection of receptor activator nuclear kappa B ligand and osteoprotegerin in odontogenic cysts and tumors. J. Oral Maxillofac. Surg. 71(11): 1886-1892.

Eriksson, T.M., Day, R.M., Fedele, S. \& Salih, V.M. 2016. The regulation of bone turnover in ameloblastoma using an organotypic in vitro co-culture model. J. Tissue Eng. 7: 2041731416669629.

Fong, E.L., Wan, X., Yang, J., Morgado, M., Mikos, A.G., Harrington, D.A., Navone, N.M. \& Farach-Carson, M.C. 2016. A 3D in vitro model of patient-derived prostate cancer xenograft for controlled interrogation of in vivo tumor-stromal interactions. Biomaterials 77: 164-172.

Fuchigami, T., Kibe, T., Koyama, H., Kishida, S., Iijima, M., Nishizawa, Y., Hijioka, H., Fujii, T., Ueda, M., Nakamura, N., Kiyono, T. \& Kishida, M. 2014. Regulation of IL-6 and IL-8 production by reciprocal cell-to-cell interactions between tumor cells and stromal fibroblasts through IL-1alpha in ameloblastoma. Biochem. Biophys. Res. Commun. 451(4): 491-496.

Harada, H., Mitsuyasu, T., Nakamura, N., Higuchi, Y., Toyoshima, K., Taniguchi, A. \& Yasumoto, S. 1998. Establishment of ameloblastoma cell line, AM-1. J. Oral. Pathol.Med.27(5): 207-212.

Khosla, S. 2001. Minireview: The OPG/RANKL/RANK system. Endocrinology 142(12): 5050-5055.

Kim, Y. \& Othmer, H.G. 2013. A hybrid model of tumor-stromal interactions in breast cancer. Bull. Math. Biol. 75(8): 13041350 .

Kumamoto, H. \& Ooya, K. 2004. Expression of parathyroid hormone-related protein (PTHrP), osteoclast differentiation factor $(\mathrm{ODF}) /$ receptor activator of nuclear factor-kappaB ligand (RANKL) and osteoclastogenesis inhibitory factor (OCIF)/osteoprotegerin (OPG) in ameloblastomas. J. Oral Pathol.Med. 33(1): 46-52.

Liu, X.Q., Kiefl, R., Roskopf, C., Tian, F. \& Huber, R.M. 2016. Interactions among lung cancer cells, fibroblasts, and macrophages in 3D co-cultures and the impact on MMP-1 and VEGF expression. PLOS ONE 11(5): e 0156268.

Luis-Ravelo, D., Antón, I., Vicent, S., Hernández, I., Valencia, K., Zandueta, C., Martínez-Canarias, Gúrpide, A. \& Lecanda, F. 2011. Tumor-stromal interactions of the bone microenvironment: in vitro findings and potential in vivo relevance in metastatic lung cancer models. Clinical \& Experimental Metastasis 28(8): 779-791.

Ottewell, P.D. 2016. The role of osteoblasts in bone metastasis. Journal of Bone Oncology 5(3): 124-127.

Proff, P. \& Romer, P. 2009. The molecular mechanism behind bone remodelling: A review. Clin. Oral Investig. 13(4): 355-362.

Qian, Y. \& Huang, H.Z. 2010. The role of RANKL and MMP-9 in the bone resorption caused by ameloblastoma. J. Oral Pathol. Med.39(8): 592-598.

Ringer, E. \& Kolokythas, A. 2017. Bone margin analysis for benign odontogenic tumors. Oral Maxillofac. Surg. Clin. North Am. 29(3): 293-300.

Sandra, F., Hendarmin, L., Kukita, T., Nakao, Y., Nakamura, N. \& Nakamura, S. 2005. Ameloblastoma induces osteoclastogenesis: A possible role of ameloblastoma in expanding in the bone. Oral Oncol. 41(6): 637-644.

Sandra, F., Hendarmin, L. \& Nakamura, S. 2006. Osteoprotegerin (OPG) binds with tumor necrosis factor-related apoptosisinducing ligand (TRAIL): Suppression of TRAIL-induced apoptosis in ameloblastomas. Oral Oncol. 42(4): 415-420.

Sathi, G.A., Inoue, M., Harada, H., Rodriguez, A.P., Tamamura, R., Tsujigiwa, H., Borkosky, S.S., Gunduz, M. \& Nagatsuka, H. 2009. Secreted frizzled related protein (sFRP)-2 inhibits bone formation and promotes cell proliferation in ameloblastoma. Oral Oncol. 45(10): 856-860.

Sathi, G.A., Tsujigiwa, H., Ito, S., Siar, C.H., Katase, N., Tamamura, R., Harada, H. \& Nagatsuka, H. 2012. Osteogenic genes related to the canonic WNT pathway are downregulated in ameloblastoma. Oral Surg. Oral Med. Oral Pathol. Oral Radiol. 114(6): 771-777.

Sathi, G.S., Nagatsuka, H., Tamamura, R., Fujii, M., Gunduz, M., Inoue, M., Rivera, R.S. \& Nagai, N. 2008. Stromal cells promote bone invasion by suppressing bone formation in ameloblastoma. Histopathology 53(4): 458-467.

Siar,C.H.\& Ng,K.H. 2014. Differential expression of transcription factors snail, slug, SIP1, and twist in ameloblastoma. J. Oral Pathol. Med.43(1): 45-52.

Siar, C.H., Tsujigiwa, H., Ishak, I., Hussin, N.M., Nagatsuka, H. \& Ng, K.H. 2015. RANK, RANKL, and OPG in recurrent solid/multicystic ameloblastoma: Their distribution patterns and biologic significance. Oral Surg. Oral Med.Oral Pathol. Oral Radiol. 119(1): 83-91.

Takebe, Y., Tsujigiwa, H., Katase, N., Siar, C.H., Takabatake, K., Fujii, M., Tamamura, R., Nakano, K. \& Nagatsuka, H. 2017. Parenchyma-stromal interactions induce fibrosis by secreting CCN2 and promote osteoclastogenesis by stimulating RANKL and CD68 through activated TGF-beta/BMP4 in ameloblastoma. J. Oral Pathol. Med. 46(1): 67-75.

Tay, J.Y., Bay, B.H., Yeo, J.F., Harris, M., Meghji, S. \& Dheen, S.T. 2004. Identification of RANKL in osteolytic lesions of the facial skeleton. J. Dent. Res. 83(4): 349-353. 
Tekkesin, M.S., Mutlu, S. \& Olgac, V. 2011. The role of RANK/ RANKL/OPG signalling pathways in osteoclastogenesis in odontogenic keratocysts, radicular cysts, and ameloblastomas . Head and Neck Pathology 5(3): 248-253.

Umezawa, A., Maruyama, T., Segawa, K., Shadduck, R.K., Waheed, A. \& Hata, J.I. 1992. Multipotent marrow stromal cell line is able to induce hematopoiesis in vivo. J. Cell Physio. 151(1): 197-205.

Vered, M., Muller, S. \& Heikinheimo, K. 2017. Ameloblastoma. In World Health Organization Classification of Head and Neck Tumours, edited by El-Naggar, A.K., Chan, J.K.C., Grandis, J.R., Takata, T. \& Slootweg, P.J. 4th. Lyon IARC. pp. 215-218.

Wendler, F., Stamp, G.W. \& Giamas, G. 2016. Tumor-stromal cell communication: Small vesicles signal big changes. Trends Cancer 2: 326-329.

Wright, J.M. \& Vered, M. 2017. Update from the 4th Edition of the World Health Organization classification of head and neck tumours: Odontogenic and maxillofacial bone tumors. Head Neck Pathol. 11(1): 68-77.

Soo Leng Lee*, Zainal Ariff Abdul Rahman \& Chong Huat Siar Department of Oral and Maxillofacial Clinical Sciences

Faculty of Dentistry

University of Malaya

50603 Kuala Lumpur, Federal Territory

Malaysia
Hidetsugu Tsujigiwa

Laboratory of Histopathology

Department of Life Science

Faculty of Science

Okayama University of Science, Okayama

Japan

Mei Hamada, Kiyofumi Takabatake, Keisuke Nakano \& Hitoshi Nagatsuka

Department of Oral Pathology and Medicine

Graduate School of Medicine

Dentistry and Pharmaceutical Sciences

Okayama University, Okayama

Japan

*Corresponding author; email: leng527@siswa.um.edu.my

Received: 18 September 2018

Accepted: 16 May 2019 